\title{
The world-class Howard's Pass SEDEX Zn-Pb district, Selwyn Basin, Yukon. Part II: the roles of thermochemical and bacterial sulfate reduction in metal fixation
}

\author{
Michael G. Gadd ${ }^{1}$ • Daniel Layton-Matthews ${ }^{1}$ • Jan M. Peter ${ }^{2}$. \\ Suzanne Paradis ${ }^{3}$ • Ian R. Jonasson ${ }^{2}$
}

Received: 25 September 2015 / Accepted: 30 June 2016 / Published online: 15 July 2016

(C) The Author(s) 2016. This article is published with open access at Springerlink.com

\begin{abstract}
The Howard's Pass district of sedimentary exhalative (SEDEX) $\mathrm{Zn}-\mathrm{Pb}$ deposits is located in Yukon Territory and comprises $14 \mathrm{Zn}-\mathrm{Pb}$ deposits that contain an estimated 400.7 Mt of sulfide mineralization grading $4.5 \%$ $\mathrm{Zn}$ and $1.5 \% \mathrm{~Pb}$. Mineralization is hosted in carbonaceous and calcareous and, to a lesser extent, siliceous mudstones. Pyrite is a minor but ubiquitous mineral in the host rocks stratigraphically above, within, and below mineralization. Petrographic analyses reveal that pyrite has a complex and protracted growth history, preserving multiple generations of pyrite within single grains. Sulfur isotope analysis of paragenetically complex pyrite by secondary ion mass spectrometry (SIMS) reveals that sulfur isotope compositions vary with textural zonation. Within the $\mathrm{Zn}-\mathrm{Pb}$ deposits, framboidal pyrite is the earliest pyrite generation recognized, and this exclusively has negative $\delta^{34} \mathrm{~S}$ values (mean $=-16.6 \pm 4.1 \%$; $n=55$ ), whereas paragenetically later pyrite and galena possess positive $\delta^{34} \mathrm{~S}$ values (mean $=29.1 \pm 7.5$ and $22.4 \pm 3.0 \%$, $n=13$ and 13, respectively). Previous studies found that
\end{abstract}

Editorial handling: D. Huston

Electronic supplementary material The online version of this article (doi:10.1007/s00126-016-0672-x) contains supplementary material, which is available to authorized users.

Michael G. Gadd

michael.gadd@canada.ca

1 Department of Geological Sciences and Geological Engineering, Queen's University, 36 Union Street, Kingston, ON K7L 3N6, Canada

2 Geological Survey of Canada, 601 Booth Street, Ottawa, ON K1A 0E8, Canada

3 Geological Survey of Canada, 9860 West Saanich Road, Sidney, BC V8L 4B2, Canada sphalerite and galena mineral separates have exclusively positive $\delta^{34} \mathrm{~S}$ values (mean $=16.8 \pm 3.3$ and $12.7 \pm 2.8 \%$, respectively; Goodfellow and Jonasson 1986). These distinct sulfur isotope values are interpreted to reflect varying contributions of bacterially reduced seawater sulfate (negative; framboidal pyrite) and thermochemically reduced seawater sulfate and/or hydrothermal sulfate (positive; galena, sphalerite, later forms of pyrite). Textural evidence indicates that framboidal pyrite predates galena and sphalerite deposition. Collectively, the in situ and bulk sulfur isotope data are much more complex than $\delta^{34} \mathrm{~S}$ values permitted by prevailing genetic models that invoke only biogenically reduced sulfur and coeval deposition of galena, sphalerite, and framboidal pyrite within a euxinic water column, and we present several lines of evidence that argue against this model. Indeed, the new data indicate that much of the base metal sulfide mineralization was emplaced below the sedimentwater interface within sulfidic muds under reducing conditions during early diagenesis. Furthermore, thermochemical sulfate reduction provided most of the reduced sulfur within the $\mathrm{Zn}-\mathrm{Pb}$ deposits.

\section{Introduction}

The Late Ordovician to Early Silurian Howard's Pass $\mathrm{Zn}-\mathrm{Pb}$ district (HPD) of sedimentary exhalative (SEDEX) deposits comprises 14 sulfide deposits that contain an estimated 400.7 Mt grading 4.5 \% $\mathrm{Zn}$ and $1.5 \% \mathrm{~Pb}$ (Kirkham et al. 2012). The HPD is located within the Selwyn Basin (Fig. 1), a metallogenic province that is primarily known for its worldclass $\mathrm{Zn}-\mathrm{Pb}( \pm \mathrm{Ag} \pm \mathrm{Ba})$ sediment-hosted deposits (Fig. 1). Other major $\mathrm{Zn}-\mathrm{Pb}$ districts in the Selwyn Basin include the Middle Cambrian Anvil district and the Middle to Late Devonian MacMillan Pass district. These districts, together with the HPD, collectively formed during a long, episodic 


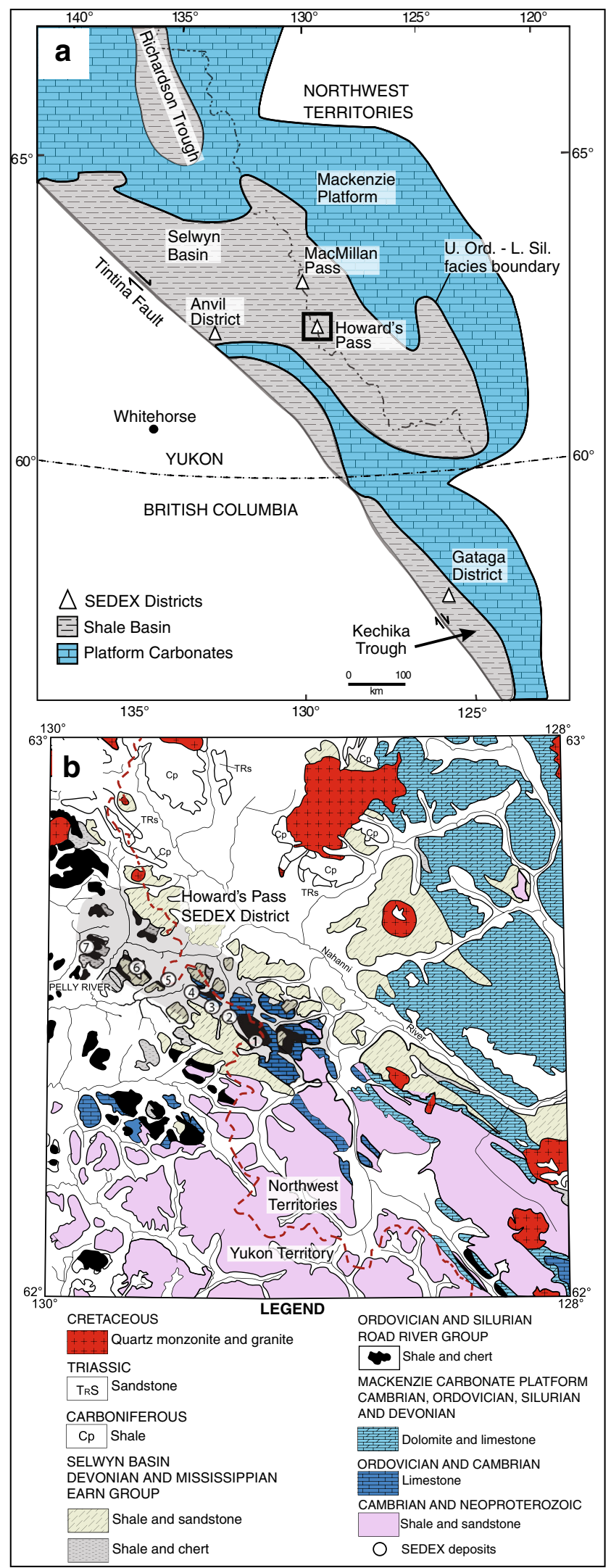

$\mathrm{Zn}$-Pb-mineralizing history that was synchronous with Lower Paleozoic evolution of the Selwyn Basin (Abbott et al. 1986).
Fig. 1 a General geologic map of the Selwyn Basin showing the major sediment-hosted, stratiform $\mathrm{Zn}-\mathrm{Pb} \pm \mathrm{Ag}$-Ba districts. b Geologic map of the Howard's Pass district showing locations of $\mathrm{Zn}-\mathrm{Pb}$ deposits and zones. 1: XY zone (XY, XY Central, and XY West deposits); 2: Brodel deposit; 3: HC zone (HC and HC West deposits); 4: Don zone (Don and Don East deposits); 5: Anniv Zone (Anniv and Anniv East deposits); 6: OP deposit; 7: Pelly North deposit (modified from Goodfellow 2004)

A common feature of the Selwyn Basin deposits is the finegrained nature of the sulfide minerals, and pyrite is a ubiquitous component of the mineralized zones and host rocks in all of these districts (e.g., Goodfellow and Jonasson 1984; Goodfellow 1987; Morganti 1979; Shanks et al. 1987). These studies focused on the sulfur isotope composition of sulfide minerals at the mineral grain scale to elucidate the source(s) of sulfur for sulfide precipitation and massive sulfide formational processes. The $\mathrm{H}_{2} \mathrm{~S}$ required to form sedimenthosted $\mathrm{Zn}-\mathrm{Pb}-(\mathrm{Ag}-\mathrm{Ba})$ deposits is commonly derived through combinations of biogenic and abiogenic sulfate reduction mechanisms (Eldridge et al. 1993; Taylor and Beaudoin 2000; Taylor 2004); however, the source(s) and pathway(s) of sulfur in Selwyn Basin SEDEX Zn-Pb deposits remain contentious (see discussions in Cooke et al. 2000; Eldridge et al. 1989; Goodfellow 1987; Goodfellow et al. 1993; Ohmoto et al. 1990; Ohmoto and Goldhaber 1997). The relative importance/predominance of either of these mechanisms is difficult to establish due to a paucity of empirical physicochemical fluid inclusion data in the HPD (and also for a majority of stratiform, sediment-hosted $\mathrm{Zn}-\mathrm{Pb}$ deposits). These data are lacking because the very fine-grained nature of hydrothermal mineral assemblages is not amenable to fluid inclusion analyses and due to a paucity of recognized feeder systems and vent complexes for a majority ( $>80 \%$ ) of these deposits (Sangster and Hillary 2000).

Previous sulfur isotope studies have measured the sulfur isotope composition of sulfide minerals obtained by mechanically or chemically separating individual minerals. There are obvious limitations to such methods, particularly considering the fine-grained nature of minerals in SEDEX deposits. This is especially problematic when a single mineral (e.g., pyrite) possesses textural complexity at the submillimeter scale. High-spatial resolution (ca. $10 \mu \mathrm{m}$ spot size) ion microprobe instruments (e.g., secondary ion mass spectrometry, SIMS) can measure in situ the sulfur isotope composition of finely intergrown sulfide minerals (Eldridge et al. 1988, 1993; Seal 2006).

Understanding the textural context of the distribution of sulfur isotope compositions among minerals may be critical to developing mineral deposit genetic models. In a study of the HYC Zn-Pb deposit in Australia, Eldridge et al. (1993) recognized $\delta^{34} \mathrm{~S}$ variability in pyrite, sphalerite, and galena. The heterogeneous nature of the sulfides was concealed in bulk analyses, but the mineral grain-scale isotope variability revealed that two processes were responsible for the 
generation of the two isotopically distinct sulfide reservoirs. Ireland et al. (2004) also investigated the sulfur isotope composition of pyrite and sphalerite in the HYC deposit with ion microprobe analyses. Although their conclusions regarding the HYC deposit genetic model differed from that of Eldridge et al. (1993), isotopic heterogeneity documented by Ireland et al. (2004) corroborated the earlier work and showed that distinct $\mathrm{H}_{2} \mathrm{~S}$ reservoirs must have existed to account for the complex isotope systematics.

Gadd et al. (2016) showed that pyrite within the HPD formed over a protracted period of time extending from synsedimentary to earliest diagenesis (py1), to early to late diagenesis (py2) to metamorphism (py3). These pyrites are texturally complex, and single grains are commonly multigenerational and textural heterogeneity varies at the submillimeter scale. Additionally, Gadd et al. (2016) showed, using laser ablation-inductively coupled plasma-mass spectrometry (LA-ICP-MS), that the trace element compositions vary with textural style. Within the $\mathrm{Zn}-\mathrm{Pb}$ deposits of the HPD, pyrite of all types is commonly intergrown with sphalerite and galena.

In this study, we use petrographic reflected light microscopy, together with field emission gun-scanning electron microscopy (FEG-ESEM) and SIMS to determine the sulfur isotope composition of the different textural styles and generations of pyrite in the host rocks and $\mathrm{Zn}-\mathrm{Pb}$ mineralization. The in situ sulfur isotope compositions are complemented by a series of bulk sulfur isotope analyses from previously unpublished sphalerite and galena mineral separates. Our objective is to investigate the relationship between the textural variability and sulfur isotope composition of pyrite in order to obtain a clearer understanding of the sulfur source(s) and pathway(s) within the sulfide deposits of the HPD.

\section{Background}

\section{Geology of the Howard's Pass district}

Deposits in the HPD are hosted in the Duo Lake Formation, which consists of carbonaceous, calcareous to siliceous mudstones (Gadd et al. 2016; Goodfellow and Jonasson 1986; Morganti 1979). Locally, the Duo Lake Formation is subdivided into informal members that, from the base to the top, comprise the Pyritic Siliceous Mudstone member (PSMS), Lower Cherty Mudstone member (LCMS), Calcareous Mudstone member (CCMS), Active member (ACTM), and Upper Siliceous Mudstone member (USMS) (Morganti 1979). The Steel Formation consists of gray bioturbated mudstone, conformably overlies the Duo Lake Formation and is locally named the Flaggy Mudstone member (FLMD; Morganti 1979). The ACTM hosts the Zn-Pb deposits. Biostratigraphic data indicate that the ACTM was deposited in the Early Silurian (ca. 440 Ma; Norford and Orchard 1985). These authors also demonstrated that the ACTM spans two conodont zones and gives a maximum depositional time interval of $5 \mathrm{My}$. Pyrite is a minor but ubiquitous component of these rocks and constitutes, on average, $4.6 \mathrm{wt} \%$ of the CCMS, $5.4 \mathrm{wt} \%$ of the ACTM, and $2.9 \mathrm{wt} \%$ of the USMS.

\section{Sediment-hosted $\mathrm{Zn}-\mathrm{Pb}$ deposits}

The ACTM is laterally extensive and has a semicontinuous northwest/southeast strike of at least $38 \mathrm{~km}$ (Fig. 1b). The XY, Don, and Anniv are the largest zones of mineralization in the HPD. Each of these three zones contains approximately $100 \mathrm{Mt}$ grading $5 \mathrm{wt} \% \mathrm{Zn}$ and $2 \mathrm{wt} \% \mathrm{~Pb}$ (Kirkham et al. 2012). The style of $\mathrm{Zn}-\mathrm{Pb}$ mineralization in each deposit is identical, and the rocks that host the deposits are assumed to be of the same age.

The ACTM is approximately $30 \mathrm{~m}$ thick and the ore mineralogy consists of sphalerite and galena. The gangue mineralogy is relatively simple, consisting of pyrite, calcite, and quartz. Semimassive sulfides are intercalated with sulfidepoor laminated carbonaceous mudstone, laminated calcareous mudstone and bedded to massive limestone. Although the ACTM is a vertically continuous unit, it has been subdivided into two visually and lithologically distinct sections (upper unit and lower unit; Goodfellow and Jonasson 1986). The lower ACTM is predominantly light to medium gray mudstone, with minor intercalations of black mudstone. The light coloration is due to high calcite (up to $80 \mathrm{wt} \%$ ) and relatively low organic carbon contents ( $<4 \mathrm{wt} \%$; Goodfellow and Jonasson 1986). Sulfide mineralization within the lower unit of the ACTM consists of massive to semimassive sphalerite and galena; stratiform sulfides are less common and, where present, highly deformed. Beds of sulfide-poor carbonaceous mudstone are thin $(<0.5 \mathrm{~m})$ and laminated and, in places, contain small ( 0.5 to $2.5 \mathrm{~cm}$ diameter) calcite nodules.

The upper ACTM is predominantly dark gray to black mudstone, with minor light gray limestone intercalations and carbonate nodules. The dark coloration is due to its high organic carbon contents (up to $8 \mathrm{wt} \%$; Goodfellow and Jonasson 1986). Well-developed laminae of cherty carbonaceous mudstone and framboidal pyrite are common. At the drill core scale, sphalerite and galena also appear to be laminated, whereas massive to semimassive sulfides are less common. Broadly, the lower unit of the ACTM is more calcareous, less carbonaceous, and less siliceous than the upper unit of the ACTM, but the grade is relatively consistent through the entire ACTM with average $\mathrm{Zn}$ and $\mathrm{Pb}$ contents of 5 and $1.6 \mathrm{wt} \%$, respectively (Kirkham et al. 2012). The average pyrite content of the lower unit of the ACTM (3.9 wt\%) is less than that in the upper ACTM (6.8 wt\%; Gadd et al., unpublished data). 


\section{Sulfide petrography and mineralogy}

Gadd et al. (2016) recently described the distribution, petrography, and trace element compositions of pyrite from the HPD, and noted the textural heterogeneity and complex paragenetic sequence. The petrographic results of Gadd et al. (2016) are briefly described below to provide context for the sulfur isotope data presented. The textural types of pyrite are framboids (Figs. 2a and 3a, b), polyframboidal clusters (Figs. 2a and 3c), stratiform layers (Figs. 2b and 3a), nodules and coarse euhedra (Figs. 2c and $3 b$ ), porphyroblasts, and metamorphic overgrowths (Figs. $2 \mathrm{~d}$ and $3 \mathrm{~b}$ ). The relative proportions of the different pyrite morphologies are fairly consistent in the CCMS, lower ACTM, USMS, FLMD, and BSSM, within which stratiform and nodular pyrite predominate (Table 1). Within the upper ACTM, framboidal pyrite is much more common and may comprise up to $70 \mathrm{vol} \%$ of the total pyrite (Table 1).

Pyrite framboids and minute ( $1-5 \mu \mathrm{m}$ diameter) euhedra (py1) consist of spherical aggregates of microcrystalline pyrite and irregular aggregates of minute pyrite crystals, respectively. Individual framboids are generally $<10$ to $20 \mu \mathrm{m}$ in diameter and less commonly up to $50 \mu \mathrm{m}$ in diameter. Framboidal py1 occurs in places as agglomerated masses of several hundred microns across, which form polyframboids. Framboidal py1 is most abundant in the upper unit of the ACTM and forms delicate laminae intercalated with carbonaceous sediments, sphalerite, and galena. Framboids are much less common in the CCMS, lower ACTM, USMS, and FLMD.

Pyrite beds (py2a), $<1 \mathrm{~mm}$ to several mm thick, comprise laminae of aggregated and intergrown subhedral to euhedral crystalline pyrite (Fig. 2b). Py2a forms wispy and discontinuous bands to well-formed continuous beds at the drill core scale. Py2a is common in the CCMS, ACTM, and USMS and is rare in the FLMD. Well-formed py2a beds overprint and preserve primary bedding of the host carbonaceous mudstones. Wispy py2a differs from laminated py1 in that the framboidal texture of the former is either overprinted
(Fig. 2b) or obliterated due to postdepositional recrystallization. Pyrite nodules (py2b) comprise round to subround masses of intergrown and aggregated subhedral pyrite crystals that commonly show radial growth patterns and herringbone textures (Fig. 2c). Nodules range in diameter from 0.5 to $>1.5 \mathrm{~cm}$ and occur throughout the stratigraphic succession. Py $2 \mathrm{~b}$ nodules commonly display complex growth textures that range from silicate inclusion-rich to inclusion-free. Etching of polished surfaces with concentrated $\mathrm{HNO}_{3}$ enhanced textures and reveals growth relationships between pyrite generations, where py $2 b$ overprinted and recrystallized polyframboidal py1.

Pyrite (py3) occurs as both euhedral crystals ( 0.1 to $5 \mathrm{~mm}$ in diameter) and narrow overgrowths $(<0.2 \mathrm{~mm}$ wide) on preexisting pyrites. Py 3 is the latest stage of pyrite growth in the HPD and overgrows all preceding generations of pyrite. Euhedral py3 crystals are commonly enclosed by quartz + calcite ( \pm chlorite) strain shadows that are oriented with the NW/SE regional cleavage; metamorphic overgrowths form veneers on diagenetic pyrites (Fig. 2d).

Sphalerite forms fine-grained disseminated (10 to $50 \mu \mathrm{m})$ to stratiform crystals concentrated along discrete laminae $(0.1 \mathrm{~mm})$ and as mixed sphalerite-galena-framboidal pyrite laminae. Nonlaminated sphalerite occurs as discordant cleavage-controlled pressure solution seams (e.g., Fig. 3b) and, less commonly, as 1- to 2-mm diameter crystalline blebs. Galena may also be stratiform together with sphalerite and/or framboidal pyrite (Fig. 3c); however, high-grade galena predominates as cleavage-controlled pressure solution seams. The timing of this pervasive pressure solution cleavage, within which sphalerite and galena are concentrated, remains contentious. Jonasson and Goodfellow (1986) propose that much of the cleavage was produced by localized compression during basinal dewatering shortly after the deposition of the ACTM (i.e., Middle Silurian). Other workers conclude that this cleavage, together with prominent thrust faulting, folding, and axial planar cleavage, formed in response to JurassicCretaceous orogenesis and subgreenschist metamorphism (Hodder et al. 2014; Martel et al. 2014; Martel 2015).
Fig. 2 Reflected light photomicrographs of pyrite of different parageneses: a framboidal pyrite (py1) intergrown with sphalerite; $\mathbf{b}$ framboidal pyrite (py1) overgrown by stratiform diagenetic pyrite (py2a; dashed white lines); $\mathbf{c}$ round, nodular diagenetic pyrite (py2b); and d metamorphic pyrite (py3) overgrowth on diagenetic py $2 b$. $s p$ sphalerite, $c c p$ chalcopyrite

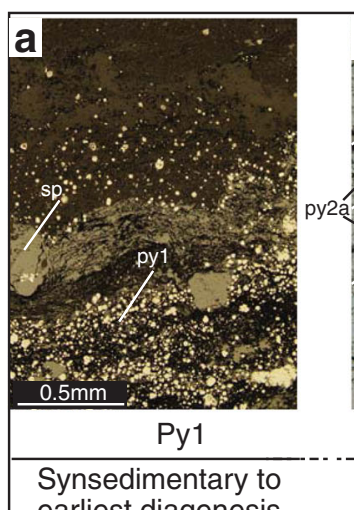

earliest diagenesis

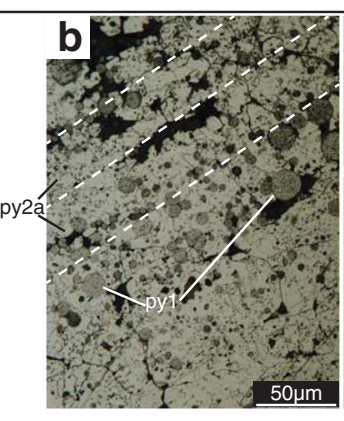

Py2a

Early to late diagenesis

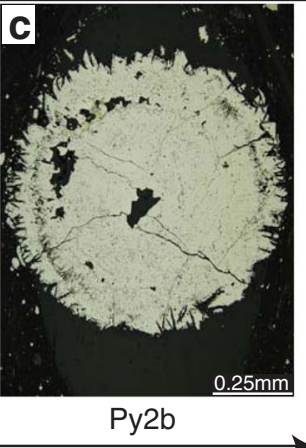

Py2b

$\longrightarrow$

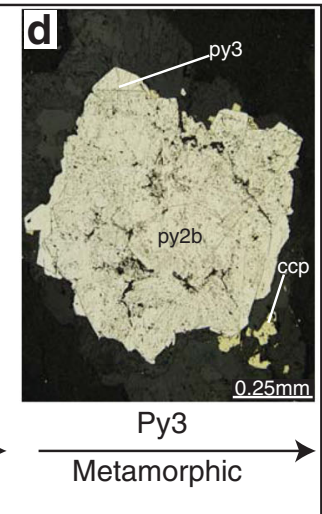



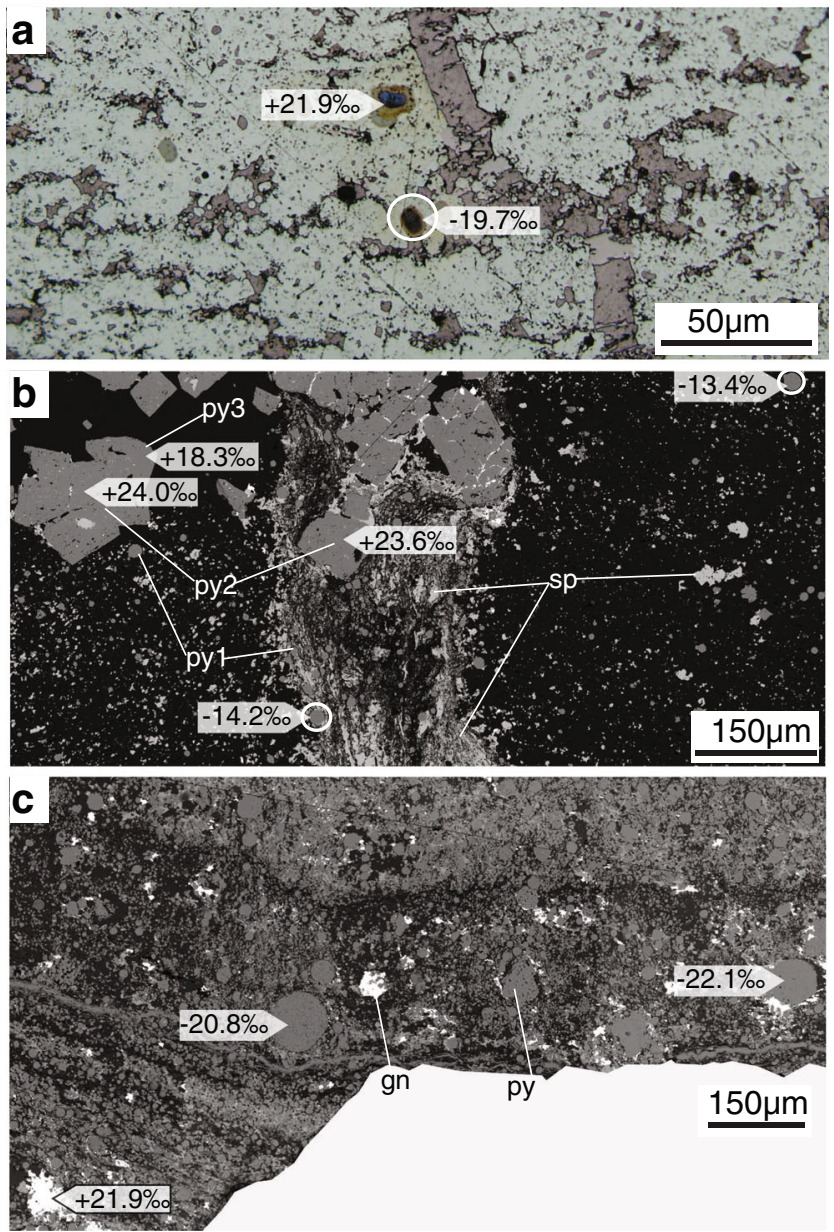

Fig. 3 Typical sulfide textures observed within the ACTM. a Reflected light photomicrograph of bedded diagenetic pyrite overgrowths on framboidal pyrite from the ACTM of the Don deposit (drill core sample Don-200-387.0). BSE images of $\mathbf{b}$ sphalerite and framboidal py1 and py2 in a tectonically modified dewatering pipe crosscutting carbonaceous mudstone with later, coarse-grained pyrite crystals (drill core sample Don-076-180.8. c Laminated framboidal and polyframboidal pyrite with abundant interstitial galena and sphalerite (grab sample XY-Adit-549.5). Locations of SIMS point analyses are shown with corresponding $\delta^{34} \mathrm{~S}$ values; single framboid analyses outlined in white circles. $s p$ sphalerite, gn galena

\section{Methods}

\section{Secondary ion mass spectrometry}

Samples were collected from 28 recent (2007-2011) diamond drill cores from the XY Central, Don, Anniv Central, Anniv East, OP West, and Pelly North deposits (Fig. 1b). Samples selected for SIMS analyses in the current study are a subset of those reported in Gadd et al. (2016)) and are from the following deposits: XY Central $(n=13)$, Don $(n=6)$, Anniv East $(n=1)$, OP West $(n=2)$, and Pelly North $(n=8)$ (ESM 1). Small $(5-15 \mathrm{~mm})$ pieces of thin section offcuts and sample slabs were embedded in $2.5-\mathrm{cm}$ diameter epoxy pucks and polished. All samples were sputter-coated with $300 \AA$ of $A u$

Table 1 Summary statistics of SIMS S isotope analyses

\begin{tabular}{|c|c|c|c|c|c|}
\hline & Mean $(\% o)$ & $\begin{array}{l}\text { Min } \\
(\% o)\end{array}$ & $\begin{array}{l}\text { Max } \\
(\% o)\end{array}$ & $\begin{array}{l}n \\
\text { (spots) }\end{array}$ & $\begin{array}{l}\text { Estimated } \\
\text { proportion of } \\
\text { total pyrite }^{\mathrm{a}}(\%)\end{array}$ \\
\hline \multicolumn{6}{|l|}{ BSSM } \\
\hline py1 & -6.9 & -9.8 & -4.6 & 3 & $<10$ \\
\hline py 2 & 19.3 & 15.0 & 26.2 & 4 & $80-90$ \\
\hline py3 & & & & n.a. & $<10$ \\
\hline Sed. pyrite ${ }^{b}$ & 23.5 & 16.2 & 29.7 & 5 & \\
\hline \multicolumn{6}{|l|}{ FLMD } \\
\hline py1 & & & & n.a. & $<10$ \\
\hline py2 & 26.5 & 10.3 & 35.7 & 15 & $80-90$ \\
\hline py3 & 25.5 & 18.6 & 30.4 & 6 & $<10$ \\
\hline Sed. pyrite ${ }^{b}$ & 5.4 & -4.4 & 13.9 & 6 & \\
\hline \multicolumn{6}{|l|}{ USMS } \\
\hline py1 & -18.0 & -21.0 & -15.7 & 7 & $<10$ \\
\hline py2 & 30.5 & 14.7 & 49.7 & 13 & $80-90$ \\
\hline py3 & 23.2 & 16.3 & 27.1 & 7 & $<10$ \\
\hline Sed. pyrite ${ }^{b}$ & 30.7 & 25.7 & 34.1 & 6 & \\
\hline \multicolumn{6}{|l|}{ ACTM } \\
\hline py1 & -16.6 & -26.1 & -7.5 & 55 & $<10-70$ \\
\hline py2 & 29.1 & 21.9 & 47.6 & 13 & $30-80$ \\
\hline py3 & 20.0 & 17.7 & 23.1 & 13 & $<10$ \\
\hline Galena & 22.4 & 17.0 & 27.3 & 13 & \\
\hline Sed. pyrite ${ }^{b}$ & 22.5 & 14.2 & 28.6 & 10 & \\
\hline \multicolumn{6}{|l|}{ CCMS } \\
\hline py1 & & & & n.a. & $<10$ \\
\hline py2 & 19.7 & 13.4 & 47.8 & 23 & $80-90$ \\
\hline py3 & 15.1 & 7.5 & 29.3 & 12 & $<10$ \\
\hline Sed. pyrite ${ }^{b}$ & 15.0 & 12.3 & 19.9 & 11 & \\
\hline
\end{tabular}

n.a. not analyzed

${ }^{\text {a }}$ Volume percent based on visual estimate

${ }^{\mathrm{b}}$ Sedimentary pyrite data from Goodfellow and Jonasson (1984)

after lapidary preparation to mitigate charging under primary ion bombardment. Analytical spots $(n=184)$ were collected on different pyrite textural types (py1, $n=65$; py2, $n=68 ;$ py $3, n=38)$ and galena $(n=13)$ from the lithological units that comprise the HPD stratigraphic section (Table 1). These spots were selected using combinations of reflected light photomicrographs and backscatter electron (BSE) imaging on a scanning electron microscope.

All SIMS analyses were performed on a Cameca IMS $4 \mathrm{f}$ Secondary Ion Mass Spectrometer at the MAF-IIC Microanalysis Facility Memorial University, St John's, Newfoundland. $\delta^{34} \mathrm{~S}$ determinations were performed by bombarding the sample with a primary ion microbeam of $350-450 \mathrm{pA}$ of $\mathrm{Cs}^{+}$, accelerated through a $10-\mathrm{keV}$ potential, and focused into a 5-15- $\mu \mathrm{m}$ diameter spot. To exclude exotic material in the polished surface from analysis, each spot was first presputtered for $120-150 \mathrm{~s}$ with a $25-\mu \mathrm{m}$-wide square 
raster applied to the beam. Depending on the minimum diameter of the critically focused primary beam during each session, a smaller square raster ( 5 to $15 \mu \mathrm{m}$ wide) was applied to the beam during analysis, to improve the homogeneity of primary ion delivery (Brueckner et al. 2015).

Instrumental mass fractionation (IMF) occurs during the production and detection of sputtered secondary ions and produces a bias between the actual ${ }^{34} \mathrm{~S} /{ }^{32} \mathrm{~S}$ of the sample and that measured by the mass spectrometer. The magnitude of IMF varies substantially between sulfide minerals. For this reason, the ${ }^{34} \mathrm{~S} /{ }^{32} \mathrm{~S}$ measured in samples of pyrite from the HPD were corrected for IMF by comparison to replicate measurements of in-house reference materials UL9B (pyrite; $\delta^{34} \mathrm{~S} 15.8 \%$ ) and KH87 (pyrite; $\delta^{34} \mathrm{~S} 0.2 \%$ ) at the beginning of and throughout each day. An identical procedure was followed for galena analyses, which used the reference material HT10 (galena; $\delta^{34} \mathrm{~S} 13.6 \%$ ). Analyses performed within a 14-min time interval routinely yield internal precisions on individual $\delta^{34} \mathrm{~S}$ determinations of better than $\pm 0.4 \%$ o $(1 \sigma)$ (Brueckner et al. 2015). Overall reproducibility, based on replicate standard analyses, is typically better than $\pm 0.5 \%$ o $(1 \sigma)$. All $\delta^{34} \mathrm{~S}$ values are reported with respect to Vienna Cañon Diablo troilite (VCDT). The sulfur isotope composition of in situ sphalerite could not be analyzed at the MAF-IIC SIMS laboratory because variations in the $\mathrm{Fe}$ content of sphalerite preclude reliable sulfur isotope ratio measurements (G.D. Layne, 2014, personal communication).

\section{Bulk mineral separates}

Samples $(n=41)$ from a single diamond drill core (XYC-029) from the XY Central deposit were collected in 1980 and provide a continuous profile across the ACTM. Rock samples were crushed, pulverized, sieved, and panned, and mineral separates of galena and sphalerite were then handpicked under a binocular microscope. Care was taken to ensure that mineral separates were pure; however, the fine-grained and intergrown nature of bedded sulfides in the HPD precluded the production of pure sphalerite and galena separates by mechanical separation in all cases, and some samples contain minor pyrite. In such pyrite-bearing samples, a chemical separation technique (Hall et al. 1988) was used whereby sphalerite or galena was liberated from pyrite by boiling in $6 \mathrm{M} \mathrm{HCl}$. For mineral separates comprised solely of sphalerite-pyrite or galenapyrite mixtures, selective digestion yielded reliable chemical separates. Samples containing both sphalerite and galena were not analyzed to avoid cross-contamination. The prepared mineral separates were analyzed for their sulfur isotope compositions following the method of Hall et al. (1988) at the University of Ottawa at various times between 1985 and 1992. Goodfellow and Jonasson (1986) presented a portion of these data $(n=3)$.

\section{Results}

\section{Sulfur isotope compositions determined using SIMS}

We report the sulfur isotope compositions for pyrite from the CCMS, ACTM, USMS, and FLMD and for galena from the ACTM (Fig. 4; ESM 1). Framboidal pyrite is variably intergrown with sphalerite, galena, and/or texturally different pyrite. Nevertheless, framboidal pyrite within the ACTM records the most negative $\delta^{34} \mathrm{~S}$ values $(-26.1$ to $-7.5 \%$ ). These measurements include single framboids (e.g., Fig. 3a, b) and polyframboidal aggregates (e.g., Fig. 3c) from the XY Central, Don, Don East, and Anniv East deposits. Pyrite framboids from the USMS of the XY Central area also have negative $\delta^{34} \mathrm{~S}$ values $(-21.0$ to $-15.7 \%$ ) .

Py $2 \mathrm{a}$ and py $2 \mathrm{~b}$ (herein referred to as py 2 ) are isotopically indistinguishable from each other within a stratigraphic unit and are, therefore, grouped into the same bins in the

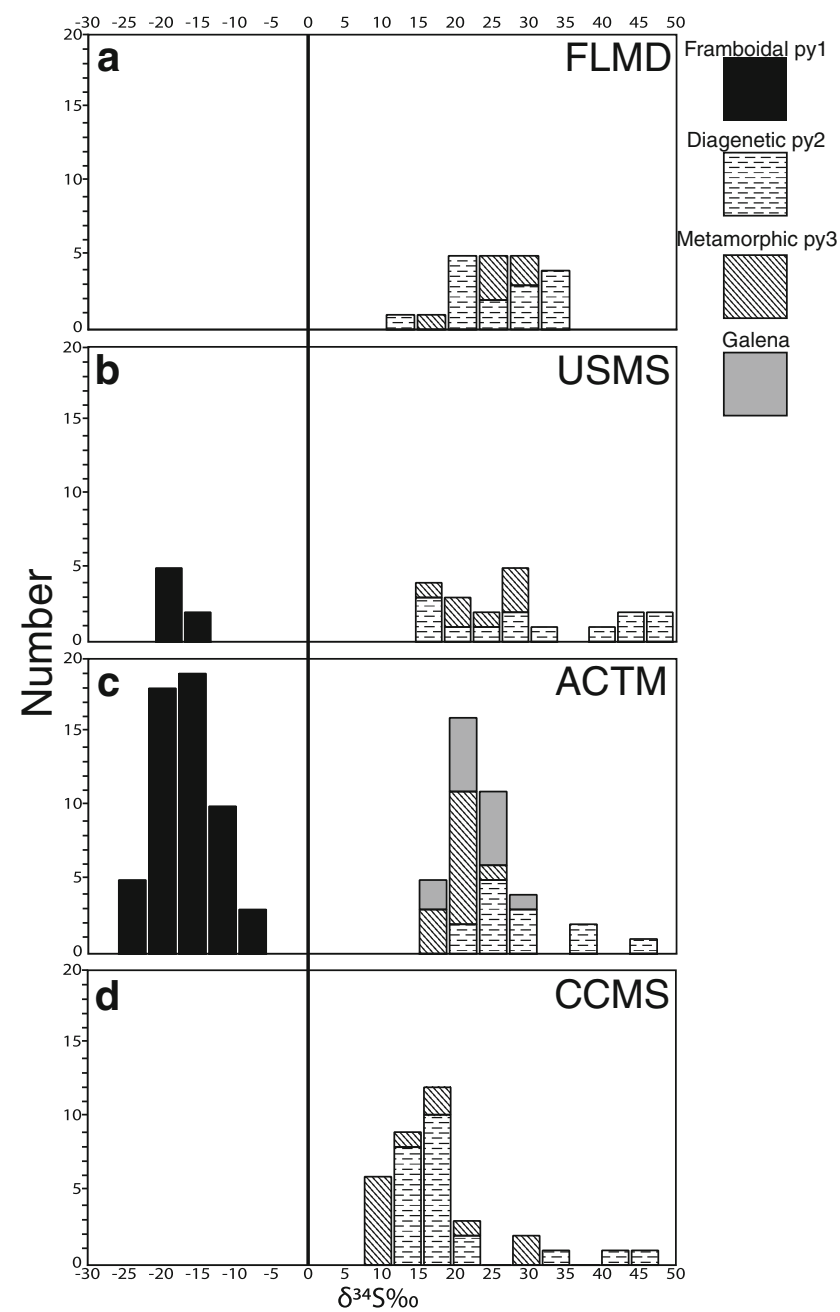

Fig. 4 Histograms of SIMS pyrite and galena $\delta^{34} \mathrm{~S}$ values in the stratigraphic units comprising the Road River Group. a Flaggy mudstone member $(F L M D)$; b upper siliceous mudstone member (USMS); $\mathbf{c}$ active member $(A C T M)$; $\mathbf{d}$ calcareous carbonaceous mudstone member (CCMS) 
histograms (Fig. 4a-d). These pyrites are exclusively isotopically positive within all units: those from the CCMS $\left(\delta^{34} \mathrm{~S}=13.4\right.$ to $47.8 \%$; Fig. $\left.4 \mathrm{~d}\right)$, ACTM $\left(\delta^{34} \mathrm{~S}=21.9\right.$ to $47.7 \%$; Fig. $4 \mathrm{c})$, and USMS $\left(\delta^{34} \mathrm{~S}=14.7\right.$ to $49.7 \%$; Fig. 4b) have broadly similar ranges of $\delta^{34} \mathrm{~S}$ values. The $\delta^{34} \mathrm{~S}$ values of pyrite from the FLMD $\left(\delta^{34} \mathrm{~S}=10.3\right.$ to $35.7 \%$; Fig. 4a) show a slightly narrower range that is lower than pyrites from the Duo Lake Formation. Samples containing py2 overgrowths on framboidal py1 or coexisting py2 and framboidal py1 have more complex sulfur isotope signatures. The highly positive $\delta^{34} \mathrm{~S}$ values of py 2 contrast markedly with highly negative values for framboidal pyl that result in $\Delta^{34} \mathrm{~S}_{\text {py2-py1 }}=40 \%$ over distances of $<50 \mu \mathrm{m}$ (e.g., Fig. 3a).

The sulfur isotope compositions of py 3 are also isotopically heavy but are generally less positive than py2. The $\delta^{34} \mathrm{~S}$ values for py 3 range from moderately to highly positive ( 7.5 to $30.4 \%$ o). Veneers of py3 on py 2 are isotopically lighter than the pyrite on which they form (Fig. 3b), but the difference of the range of $\delta^{34} \mathrm{~S}$ values (1 to $20 \%$ ) is not as pronounced as that between py1 and py2.

Sulfur isotope compositions of galena were determined for two samples $(n=13)$, where galena shares grain boundaries with py1 and py3. The sulfur isotope compositions of galena are highly positive (17.0 to $27.3 \%$ ) and are, on average, 39.0 $\%$ heavier than coexisting framboids (e.g., Fig. 3c). In one sample, Don-200-383.7 from the ACTM, galena, and py3 are adjacent and have almost identical average sulfur isotope compositions (21.2 and $21.5 \%$, respectively).

\section{Bulk sulfide separates}

The sulfur isotope compositions of sphalerite $(n=35)$ and galena $(n=21)$ mineral separates were measured in samples collected from the CCMS, ACTM, and USMS (ESM 2). The $\delta^{34} \mathrm{~S}$ values of galena and sphalerite in the ACTM are positive and range from 8.5 to $19.5 \%$ and 12.6 to $23.3 \%$, respectively (Fig. 5a). The $\delta^{34} \mathrm{~S}$ values of both minerals display minor vertical fluctuations throughout the stratigraphic section; however, there is an overall decrease from the base to the top of the ACTM (Fig. 5a). Coexisting sphalerite and galena were analyzed in 12 of these samples, and sphalerite is consistently heavier than galena in each of these coexisting pairs.

\section{Discussion}

The sulfur isotope data for pyrite determined using SIMS starkly contrast previously published data for bulk analyses of pyrite separates (Table 1; Goodfellow and Jonasson 1984; Goodfellow 1987). These differences between SIMS and bulk sample data may be explained by one or more of the following: (1) the presence of finely intergrown, texturally complex pyrite of multiple generations (Fig. 2) in bulk pyrite separates;

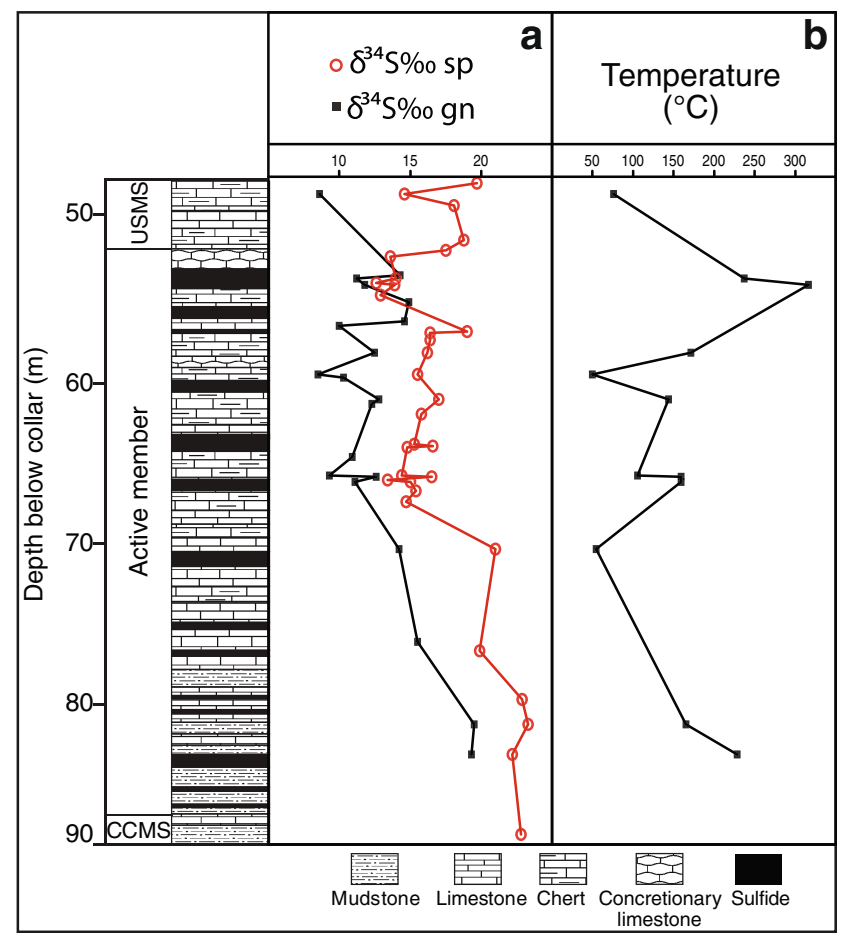

Fig. 5 Stratigraphic distributions of $\delta^{34} \mathrm{~S}$ values as determined by bulk mineral separation for a sphalerite and galena; $\mathbf{b}$ calculated fractionation temperatures (Kajiwara and Krouse 1971; modified from Goodfellow 2004)

(2) the presence of sulfide mineral inclusions that could not be removed using mineral separation techniques; and (3) sample suitability (i.e., primary py1 vs. secondary pyrite py2). For example, a typical pyrite separate may consist of a cluster of framboidal pyrite overgrown and/or partly replaced by later diagenetic pyrite (Fig. 6a). In this example, multiple pyrite generations were only revealed by close inspection using ESEM backscatter imaging. The sulfur isotope composition of this grain is $21.0 \%$ (Fig. 6b). A small polyframboidal cluster is $-16.4 \%$ and nearby diagenetic pyrite is $\sim 29 \%$ (Fig. 6c).

Each part of this sample contains varying amounts of round to subround pyrite grains of similar size, but not all of the round pyrite grains are framboidal in nature (i.e., primary); rather, some spheroidal pyrite grains are secondary. Therefore, we follow the convention of Ohfuji and Rickard (2005) in defining framboidal pyrite as "microscopic spheroidal to subspheroidal clusters of equidimensional and equimorphic crystals." Although this may seem solely an as issue of semantics, differentiating between primary framboidal and secondary spheroidal pyrite has important petrogenetic implications in the HPD (Gadd et al. 2016).

\section{Sulfur isotope disequilibrium}

In the ACTM of the HPD, galena and sphalerite are interstitial to pyrite framboids. Galena and framboidal pyrite share grain 
Fig. 6 An example of framboidal and diagenetic pyrite from mineralized ACTM (sample XYAdit-386.2). a BSE image of diagenetic pyrite replacing and overgrowing framboids, which are outlined in white. b Reflected light photomicrograph of pyrite showing the location of SIMS analysis and the corresponding $\delta^{34} \mathrm{~S}$ value. c Reflected light photomicrograph of framboidal and diagenetic pyrite showing the locations of SIMS analyses and the corresponding $\delta^{34} \mathrm{~S}$ values
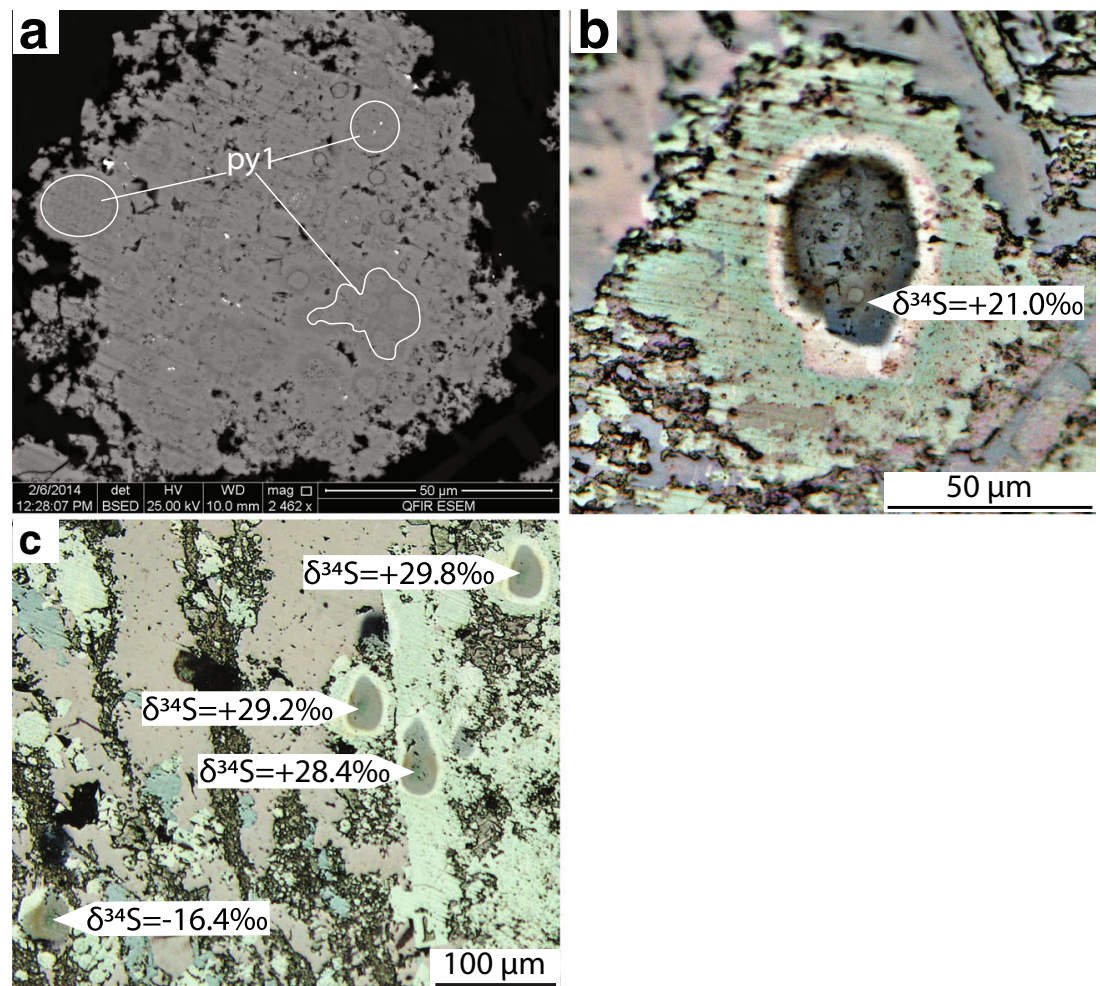

boundaries without evidence for replacement, suggesting that textural equilibrium was attained between these minerals (Fig. 3c). However, SIMS analyses of coexisting galena and nearby $($ ca. $500 \mu \mathrm{m})$ framboidal pyrite grains reveal that $\delta^{34} S_{\text {galena }}>\delta^{34} S_{\text {pyrite }}$ (Fig. $4 c$ ), indicating that isotopic equilibrium was not established between these minerals. As such, these isotopic data cannot be used to estimate formation temperatures. Isotopic disequilibrium implies that galena and pyrite precipitated at different times or from different sulfur sources (Ohmoto and Goldhaber 1997). Sphalerite was not analyzed with SIMS in the present study; however, sulfur isotopic compositions of bulk separates of coexisting sphalerite and galena reveal that $\delta^{34} S_{\text {sphalerite }}>\delta^{34} S_{\text {galena }}$ for the ACTM (Fig. 5a). Microscopic textures indicate that sphalerite and galena are in textural equilibrium, suggesting that they are cogenetic. Because $\delta^{34} S_{\text {sphalerite }}>\delta^{34} S_{\text {galena }}$ suggests that sphalerite and galena are in isotopic equilibrium (ESM 3), equilibrium fractionation temperatures can be estimated for this mineral pair (Kajiwara and Krouse 1971). The range of estimated temperatures $\left(50\right.$ to $320^{\circ} \mathrm{C}$; Fig. 5 b), with mean and median temperatures of $160{ }^{\circ} \mathrm{C}$, is consistent with temperatures estimated for other sediment-hosted $\mathrm{Zn}-\mathrm{Pb}$ deposits (Cooke et al. 2000) and geologically reasonable, based on metal solubility considerations (Lydon 1983). We note that despite great care in preparing sphalerite and galena separates for sulfur isotope analyses, the fine-grained nature of these minerals likely hindered pure separation; however, $\delta-\delta$ plots indicate that isotopic equilibrium existed between this mineral pair (ESM 3). Additionally, Jurassic to Cretaceous orogenesis resulted in significant textural modification of base metal sulfides in the HPD (Hodder et al. 2014; Martel et al. 2014; Martel 2015), and this may have resulted in partial isotopic re-equilibration between sphalerite and galena (Crowe 1994). The similarity of down-hole topological profiles of the sulfur isotopic compositions of sphalerite and galena (Fig. 5a) suggests that original, premetamorphic sulfur isotope compositions are at least partly retained.

\section{Source(s) of reduced sulfur}

In most cases, the predominant source of sulfur in stratiform, sediment-hosted $\mathrm{Zn}-\mathrm{Pb}-(\mathrm{Cu}-\mathrm{Ag}-\mathrm{Ba})$ deposits is interpreted to be seawater sulfate (Leach et al. 2005, 2010). Magmatic sulfur is not considered to be a major component in the HPD because of the lack of volumetrically important igneous rocks in the immediately underlying footwall succession (Goodfellow et al. 1993). However, the processes by which sulfate is reduced to sulfide and delivered to the depositional site are still debated and remain contentious because there are several possible mechanisms to generate the reduced sulfur (Ohmoto and Goldhaber 1997). The most relevant processes for the deposits of the HPD are (1) in situ bacterial sulfate reduction (BSR), either within the ambient water column or within the shallow seafloor (Goodfellow 1987; Goodfellow et al. 1993; Shanks et al. 1987; Turner 1992); and (2) in situ BSR combined in varying proportions with thermochemical sulfate reduction 
(TSR), either within the water column or within the shallow seafloor (Cooke et al. 2000; Ireland et al. 2004; Leach et al. 2010; Wilkinson 2014).

\section{Bacterial sulfate reduction}

BSR is a form of anaerobic respiration in which sulfate is the terminal electron acceptor. Sulfate likely undergoes several dissimilatory steps before complete reduction to sulfide (Berner 1989; Froelich et al. 1979) but is typically expressed as the following simplified reaction:

$2 \mathrm{CH}_{2} \mathrm{O}+\mathrm{SO}_{4}{ }^{2-} \rightarrow 2 \mathrm{HCO}_{3}^{-}+\mathrm{H}_{2} \mathrm{~S}$.

Sulfide generated during BSR may possess $\delta^{34} \mathrm{~S}$ values that range from extremely negative to positive, which is a function of whether the environment is open (e.g., water column) or closed (e.g., sediment-porewaters) to the diffusion of sulfate. Negative $\delta^{34} \mathrm{~S}$ values exist because of the large kinetic fractionation between sulfate and sulfide associated with BSR. In an open system with unlimited sulfate supply, biogenic sulfide possesses negative $\delta^{34} \mathrm{~S}$ values that may be recorded in pyrite. Alternatively, in a sulfate-limited closed system, progressive BSR shrinks the sulfate reservoir and increases the $\delta^{34} \mathrm{~S}$ values of sulfide in a Rayleigh-type fractionation. Throughout the Phanerozoic, the fractionation between parent sulfate and daughter sulfide, expressed as $\Delta^{34} \mathrm{~S}_{\mathrm{SO} 4-\mathrm{H} 2 \mathrm{~S}}$, is ca. $45 \pm 20 \%$ o (Sweeney and Kaplan 1980; Strauss 1999); however, BSR is not strictly a steady-state process and the range of $\Delta^{34} \mathrm{~S}$ is known to vary in natural environments as a function of sulfate reduction rate, type of organic carbon reduced, and concentration of dissolved sulfate (Leavitt et al. 2013).

Biogenic sulfide is recognized as a major component in some sediment-hosted $\mathrm{Zn}-\mathrm{Pb}$ districts (e.g., Irish ore fields), particularly where a vast majority of the base-metal sulfides possess negative $\delta^{34} \mathrm{~S}$ values (Fallick et al. 2001; Wilkinson et al. 2005). Biogenic sulfide has also been implicated as the predominant source of sulfur for base-metal sulfides of the HPD (Goodfellow and Jonasson 1984; Goodfellow 1987; Turner 1992; Goodfellow et al. 1993); however, the contribution of BSR sulfur to $\mathrm{Zn}-\mathrm{Pb}$ mineralization is not obvious here because all of the sphalerite, galena, and nonframboidal pyrite have positive (»0\%o) $\delta^{34} \mathrm{~S}$ values. Goodfellow (1987) proposes that these positive values are related to long-term, persistent (ca. $50 \mathrm{My}$ ) depletion of marine sulfate in a stagnant, restricted basin. In a closed (or partly closed) system, $\delta^{34} \mathrm{~S}$ values would increase stratigraphically upward due to Rayleigh fractionation; however, the bulk sphalerite and galena data do not correspond to this expected behavior. Rather, the sulfur isotope compositions of both sphalerite and galena progressively decrease from the stratigraphic base to the top of the ACTM (Fig. 5a). These data, therefore, do not support a model in which sulfide deposition took place near the end of a stagnant cycle from a highly fractionated source of reduced sulfur (Goodfellow 1987). Additionally, according to the model of Goodfellow (1987), framboidal pyrite, sphalerite, and galena coevally precipitated as chemical sediments in a euxinic water column. However, the isotopic disequilibrium between framboids and galena does not support this model. Additional sulfur pathways must have operated to account for the isotope systematics preserved in the HPD.

\section{Thermochemical sulfate reduction}

TSR is an abiogenic process by which sulfate is reduced in the presence of heat and reduced species. One of the possible reaction paths for TSR is similar to that of BSR, whereby labile organic carbon is thermolytically oxidized by reducing aqueous sulfate to sulfide (Machel 2001). The by-products of TSR are similar to those produced by BSR; however, TSR requires higher temperatures $\left(>100-140{ }^{\circ} \mathrm{C}\right)$ that generally do not sustain microbial life (Machel 2001). Although the end products of TSR and BSR are similar, the sulfur isotope composition of sulfide minerals can be used to distinguish between these processes (Machel 2001). The kinetic fractionation of sulfur isotopes during TSR is temperature dependent, where higher temperatures result in smaller fractionations between the parent sulfate and daughter sulfide (Machel et al. 1995). Experimentally determined $\Delta^{34} \mathrm{~S}_{\mathrm{SO} 4-\mathrm{H} 2 \mathrm{~S}}$ values for TSR indicate kinetic fractionations of 20,15 , and $10 \%$ at 100, 150, and $200{ }^{\circ} \mathrm{C}$, respectively (Machel et al. 1995). A catalyst (e.g., $\mathrm{H}_{2} \mathrm{~S}$ ) is also required for TSR to proceed at geologically reasonable rates, but once TSR is established, it is essentially autocatalyzed by the production of $\mathrm{H}_{2} \mathrm{~S}$ if high temperatures are sustained (Goldhaber and Orr 1995). Rayleigh-type fractionation is also possible for TSR in sulfate-limited environments.

TSR has been invoked as an important process in both vent-proximal and vent-distal SEDEX deposits (Leach et al. 2010; Wilkinson 2014). Cooke et al. (2000), Ireland et al. (2004), and Huston et al. (2006) suggested that dissolved sulfate was a major component of metalliferous brines that formed the Paleoproterozoic $\mathrm{HYC} \mathrm{Zn}-\mathrm{Pb}-\mathrm{Ag}$ deposit in Australia. In their model, dense brines exhaled into an anoxic water column and ponded on the seafloor. Metal sulfide precipitation was triggered by biogenically reduced sulfur that diffused into the brine from sediments below and from the water column above; this $\mathrm{H}_{2} \mathrm{~S}$ catalyzed TSR in the basal portion of the ponded hydrothermal brine (Ireland et al. 2004). Accordingly, sulfur isotopic signatures of both BSR and TSR are recorded in sulfides at HYC with values ranging from -5 to $10 \%$ and $5 \%$, respectively (Ireland et al. 2004). These ranges overlap; however, Ireland et al. (2004) were able to differentiate the products of BSR and TSR by measuring in situ the sulfur isotope compositions of sphalerite and pyrite with paragenetically distinct textural varieties. 
It is likely that TSR by hydrothermal fluids played an important role in the formation of SEDEX deposits in the HPD in a manner similar to HYC. The negative $\delta^{34} \mathrm{~S}$ values for pyrite framboids are readily explained by BSR of ambient seawater sulfate; however, the positive $\delta^{34} \mathrm{~S}$ values of galena, sphalerite, and later pyrite (py2-py3) cannot be explained solely by closed system BSR. Addition of TSR sulfur does not require prolonged, closed system BSR in the ambient water column. Although the sulfur budget and oxidation state of the hydrothermal fluids for the HPD are unconstrained, the calculated low temperatures likely preclude the transport of reduced sulfur together with base metals in the same hydrothermal fluid (Cooke et al. 2000). Assuming that the initial $\delta^{34} \mathrm{~S}_{\text {sulfate }}$ value was approximately $30 \%$ and that $\Delta^{34} \mathrm{~S}_{\mathrm{SO} 4-\mathrm{H} 2 \mathrm{~S}}$ was $10-20 \%$, the ranges of $\delta^{34} \mathrm{~S}$ values for sphalerite (12.6 to $23.3 \%$ ) and galena ( 8.5 to $19.5 \%$ ) are consistent with TSR at 100 to $200{ }^{\circ} \mathrm{C}$ (Machel et al. 1995).

\section{Secular distribution of sulfur isotopes and depositional environment}

Goodfellow and Jonasson (1984) were the first to document secular variability of the sulfur isotope composition of pyrite in the Selwyn Basin (Fig. 7). According to their model, basinal restriction led to redox stratification and stagnation in the ambient marine water column. Prolonged (up to $50 \mathrm{My}$ ) stagnant conditions were marked by BSR and the water column was not replenished due to closed or partly closed hydrologic conditions. This, in turn, led to the buildup of $\mathrm{H}_{2} \mathrm{~S}$ and establishment of euxinic conditions in the ambient water column. The reduced sulfur was fixed by hydrothermal aqueous ferrous iron in the water column and the iron sulfide particles (i.e., pyrite or metastable precursor minerals) settled as chemical sediments, together with pelagic sediments. In this model, the consequence of extensive pyrite burial and BSR under restricted conditions was that the $\delta^{34} \mathrm{~S}$ values of the pyrite progressively increased until sulfate was replenished; pyrite formed subsequent to basin ventilation was isotopically lighter and was confined to sediments, with reduced sulfur derived from porewater sulfate (Goodfellow and Jonasson 1984; Goodfellow 1987). One such period of stagnation coincided with the deposition of the host rocks and formation of the HPD deposits (Goodfellow and Jonasson 1984). This stagnation period was interpreted to be coeval with the Duo Lake Formation, beginning in the Lower to Middle Ordovician and ending in the Middle Silurian (Fig. 7); Goodfellow (1987) suggested that the apex of this stagnant period was marked by near complete sulfate reduction because the $\delta^{34} \mathrm{~S}$ value of pyrite (ca. 50\%o) exceeds that of coeval ambient seawater sulfate ( 28\%; Claypool et al. 1980; Kampschulte and Strauss 2004). Positive isotope excursions in the secular pyrite trend are purported to exist because of enhanced pyrite burial, basin restriction, and stagnation over protracted time periods.

To understand any secular trend in the sulfur isotope compositions of pyrite, it is critical to first establish the relative paragenetic sequence under which the mineral formed. Gadd et al. (2016) demonstrated that pyrite in the HPD is texturally complex, consisting of discrete grains, or agglomerations thereof, that contain multiple generations of growth ranging from synsedimentary to earliest diagenetic (py1), diagenetic (py2), and metamorphic (py3). Significantly, our in situ SIMS data show two populations of $\delta^{34} \mathrm{~S}$ values that correspond in position with pyrite morphology (Fig. 7). Diagenetic py2 mimics the trend of the pyrite curve, whereas framboidal py1 is negative and far removed from the pyrite trend (Fig. 7). According to the model of Goodfellow (1987), the earliest pyrite generation in the ACTM and USMS should possess $\delta^{34} \mathrm{~S}$ values that fall on or near the secular pyrite trend in their respective time-stratigraphic horizons. Framboidal pyrite is the earliest pyrite generation that formed in the HPD, and likely records the sulfur isotope composition of reduced pore fluids near the sediment-water interface prior to

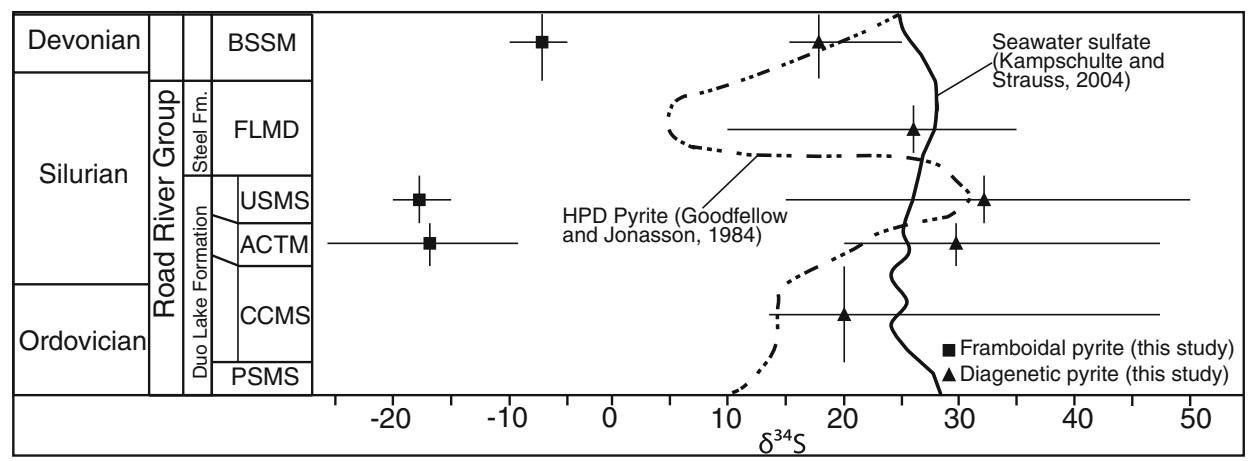

Fig. 7 Secular distribution of sedimentary pyrite (Goodfellow and Jonasson 1984) and seawater sulfate (Kampschulte and Strauss 2004) $\delta^{34} \mathrm{~S}$ values with SIMS $\delta^{34} \mathrm{~S}$ values of framboidal (square) and diagenetic (triangle) pyrite. Horizontal and vertical lines through the markers are the ranges of values measured by SIMS and the stratigraphic range, respectively. Note the similarities between $\delta^{34} \mathrm{~S}$ values of diagenetic pyrite of this study and sedimentary pyrite of Goodfellow and Jonasson (1984). These are consistently higher compared with those of framboidal pyrite (modified from Goodfellow and Jonasson 1984) 
significant closed system BSR (Strauss 1997, 1999). The same cannot be said for diagenetic py2, however, because this pyrite formed after the framboids precipitated (Fig. 3a).

The secular pyrite trend from the Selwyn Basin has been applied globally in several ore deposits studies, particularly for models that rely primarily on biogenic sulfide (Goodfellow and Peter 1996; Shanks and Seyfried 1987; Shanks et al. 2014; Turner 1992). Magnall et al. (2016) present SIMS sulfur isotope analyses of pyrite from the Middle to Late Devonian MacMillan Pass district of shale-hosted $\mathrm{Zn}-\mathrm{Pb}-\mathrm{Ag}-\mathrm{Ba}$ deposits, Yukon. Analogously to the HPD, framboidal pyrite is the paragenetically earliest sulfide in massive sulfide mineralization. Framboids there possess light sulfur isotope compositions (ca. $-25 \%$ ) and paragenetically later pyrite possesses positive $\delta^{34} \mathrm{~S}$ values (»0\%o; Magnall et al. 2016). This is significant because both the HPD and MacMillan Pass deposits are type localities that Goodfellow (1987) used to define the pyrite secular trend. If prolonged periods of stagnation existed in the Selwyn Basin prior to the introduction of metalliferous hydrothermal fluids, then this should be recorded in the paragenetically earliest sulfide. This is not the case as both localities, in their respective mineralized time-stratigraphic horizons, contain framboids with negative $\delta^{34} \mathrm{~S}$ values (this study; Magnall et al. 2016).

Goodfellow (1987) and Turner (1992) propose that the HPD and MacMillan pass deposits formed in response to global anoxic events, but paragenetically distinct sulfur isotope compositions demonstrate that the secular pyrite trend does not reflect the sulfur cycle evolution in the Selwyn Basin. It is therefore unlikely that this trend constrains a global cycle; however, the rocks that host the $\mathrm{Zn}-\mathrm{Pb}$ deposits of the HPD straddle the OrdovicianSilurian boundary (Norford and Orchard 1985) and the pyrite trend has also been advocated for enhanced pyrite burial under euxinic conditions for contemporaneous stratigraphic sections in other localities (Hammarlund et al. 2012). Although it is clear that $\delta^{34} \mathrm{~S}_{\text {sulfide }}$ values are environmentally controlled, it is important to emphasize that positive $\delta^{34} \mathrm{~S}$ values in pyrite do not uniquely indicate BSR of a depleted sulfate reservoir (Jørgensen et al. 2004). Leavitt et al. (2013) demonstrate that rapid sulfate reduction decreases sulfate-sulfide fractionation. Moreover, this fractionation is not necessarily steady state because the rate of BSR may change in response to different environmental parameters (such as fluxes of labile organic matter, dissolved sulfate concentration, temperature; Leavitt et al. 2013). Jones and Fike (2013) investigated sulfide-sulfate relationships at the Ordovician-Silurian boundary at Anticosti Island, Canada. There, positive excursions in $\delta^{34} S_{p y}$ are absent in coeval $\delta^{34} \mathrm{~S}_{\text {sulfate. }}$. Decoupling of the sulfide-sulfate sulfur isotope system implies that enhanced pyrite burial is not responsible for the positive excursion in this area, but rather that other environmental factors, such as chemocline migrating downward in sediments, modified the $\Delta^{34} \mathrm{~S}_{\mathrm{SO} \text {-H2S }}$ value (Jones and Fike 2013). Similarly, Borowski et al. (2013) suggested that positive $\delta^{34} \mathrm{~S}$ values in stratiform, authigenic pyrite are the result of rapid anaerobic sulfate respiration above the sulfate-methane transition in organic-rich sediments. Without any knowledge of the sulfur isotope composition of coeval sulfate, it is not possible to fully assess sulfur cycling in the HPD or the predominant mechanisms that produced ${ }^{34} \mathrm{~S}$-enriched sulfide; however, the intragranular textural and sulfur isotope variability in pyrite was not produced by a single-stage sulfate reduction mechanism.

\section{$\mathrm{Zn}-\mathrm{Pb}$ deposit genesis in the HPD}

Gadd et al. (2016) argued against a syngenetic, purely exhalative model and instead proposed that $\mathrm{Zn}-\mathrm{Pb}$ deposits within the HPD formed predominantly during diagenesis. This argument was based on the presence of several generations of pyrite formation in the ACTM and the distribution of trace elements among these pyrite generations. The sulfur isotope compositional data presented here corroborate the findings of Gadd et al. (2016) and allow refinement of the genetic model proposed therein.

In our proposed model, the dense brine accumulated in a depression floored by water-saturated hemipelagic sediments. Ambient seawater originally present in pore spaces was eventually displaced by denser brine (Sangster and Hillary 2000). One hundred meters below the seafloor, the porosity of silt- to clay-sized muds was approximately $50 \%$, and it increased exponentially to the sediment-water interface (Einsele 2000). As newly deposited sediments are generally porous and permeable, it is reasonable to assume this to be the case for the sediments of the ACTM prior to the introduction of metalliferous fluids. It is likely that the dense brine settled onto the seafloor, and some of it sank into porous and permeable carbonaceous muds (Fig. 8a). It is also likely that the brine did not precipitate all transported metals in the water column because sulfate dissolved within the brine must first have been reduced to sulfide (Goodfellow 1987). Sulfidic porewaters originally present in the sediment pore spaces (generated by BSR of seawater sulfate) were eventually displaced by dense brine that descended into the sulfidic muds (Fig. 8a). In terms of $\mathrm{H}_{2} \mathrm{~S}$ generation, BSR was the most important process prior to the introduction of metalliferous fluids because sulfidic porewaters served as the catalyst $\left(\mathrm{H}_{2} \mathrm{~S}\right)$ necessary for TSR to occur.

Following the introduction of metalliferous brines, TSR superseded BSR because these fluids were too warm $\left(>100{ }^{\circ} \mathrm{C}\right.$ ) to support significant bacterial activity. In the early stage of hydrothermal activity, TSR was likely restricted to the lowermost water column, near the sediment-water interface (Fig. 8a). Continued venting of dense brine and its ponding/ accumulation resulted in its downward percolation into porous unconsolidated muds, where TSR reduced seawater sulfate by the oxidation of labile organic carbon (Fig. 8b).

Calcite is a major component of the ACTM. The calcite is characterized by negative $\delta^{13} \mathrm{C}$ values $(-1$ to $-6 \%$ ), whereas organic carbon has values of ca. $-28 \%$ (Goodfellow and 

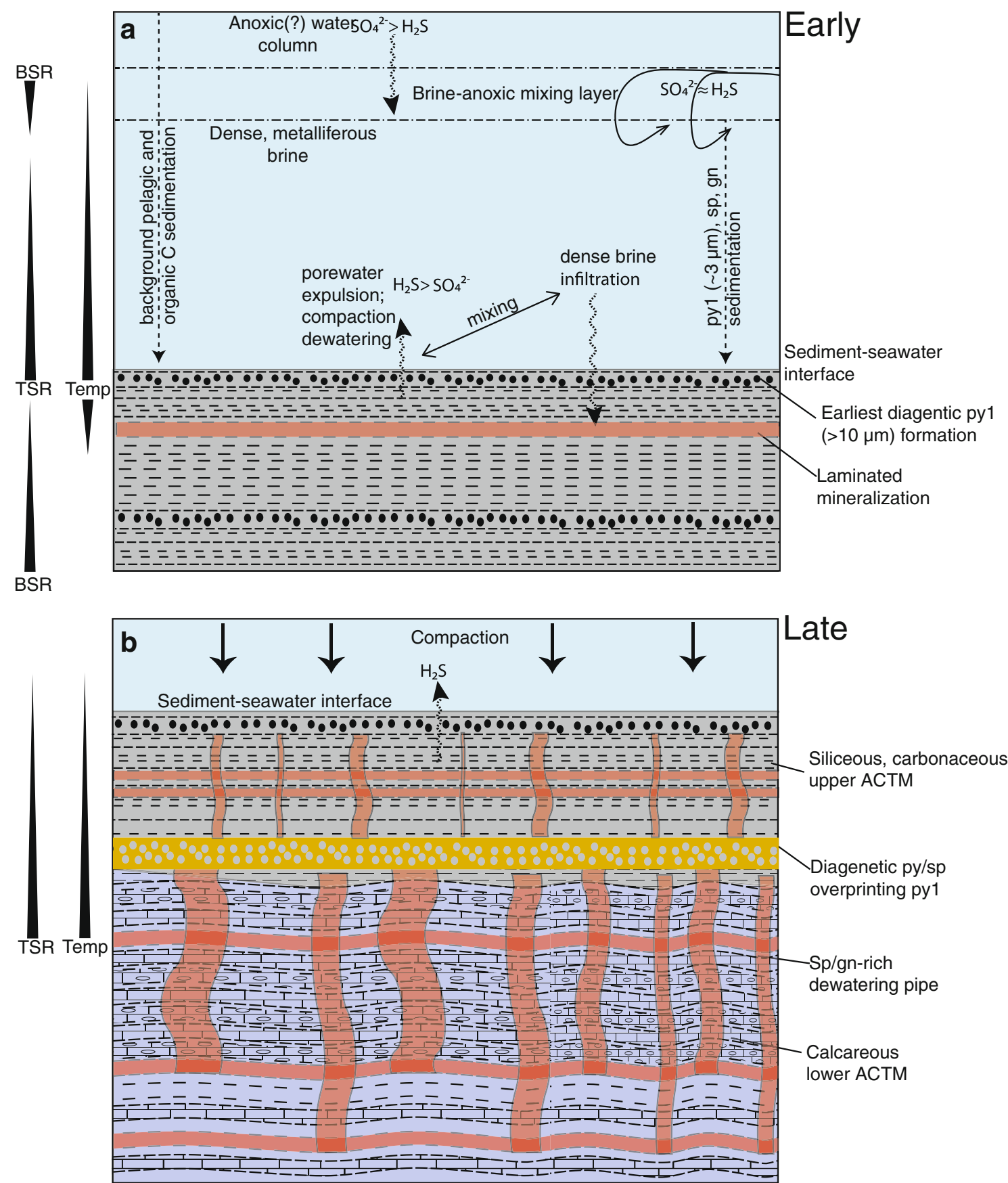

Fig. 8 A schematic model for the formation of SEDEX deposits in the HPD. The model accounts for the SIMS sulfur isotope data and illustrates the controls on sulfate-sulfide distribution and sulfate reduction processes. a Synsedimentary sulfide deposition is accompanied by dense brine sinking into permeable muds, where metals and sulfate are transported together. Dense brine sinking displaces less dense sulfidic

Jonasson 1986). The origin of the calcite is uncertain, but the negative values for calcite are indicative of $\mathrm{CO}_{2}$ produced during the oxidation of organic carbon. There is also abundant nodular calcite within the ACTM, which suggests that authigenic precipitation of calcite occurred. Although biogenic and abiogenic sulfate reduction both oxidize organic carbon porewaters and promotes early TSR. b Sinking brines percolating into muds precipitate diagenetic sulfide that form overgrowths on pre-existing sulfides and calcite that is intercalated with carbonaceous sediments. Loss of permeability is likely followed by vertical compaction and dewatering, which promotes mixing at the sediment-water interface (no scale implied; adapted and modified from Ireland et al. 2004; Gadd et al. 2016)

and produce $\mathrm{CO}_{2}, \delta^{13} \mathrm{C}$ values alone cannot unambiguously discriminate between the two processes (Machel et al. 1995; Machel 2001). The moderately negative $\delta^{13} \mathrm{C}$ values may be explained by the interaction of the hydrothermal fluid with the host sediment. Alternatively, organic matter remineralization may have occurred via methanogenesis, 
$2 \mathrm{CH}_{2} \mathrm{O}+$ microbes $\rightarrow \mathrm{CH}_{4}+\mathrm{CO}_{2}$,

subsequent to the depletion of sulfate in reducing sedimentporewaters (Berner and Raiswell 1983; Froelich et al. 1979). Methanogenesis is a very common process in carbonaceous marine sediments and occurs where organic matter accumulates on the seafloor. Coleman and Raiswell (1981) show that organic matter fermentation involves extreme $\delta^{13} \mathrm{C}$ fractionation that generates positive $\mathrm{CO}_{2}(+15 \% o)$ and negative methane. This process has been demonstrated to occur in some modern seafloor hydrothermal deposits (Guaymas Basin, Peter and Shanks 1992) and has been proposed to occur in some sediment-hosted, stratiform $\mathrm{Zn}-\mathrm{Pb}$ deposits (Red Dog, Johnson et al. 2004; MacMillan Pass, Magnall et al. 2016). It is likely that methanogenesis operated to some degree in carbonaceous sediments that host mineralization in the HPD; however, at present, there are insufficient data to validate or refute the role of this mechanism in the formation of authigenic carbonate-bearing rocks in the HPD.

Based on positive sulfur isotope values for sphalerite and galena (Fig. 5a) and negative carbon isotope values for calcite (Goodfellow and Jonasson 1986), we suggest TSR generated $\mathrm{CO}_{2}$ in situ contemporaneously with metal sulfide deposition within carbonaceous muds. Sulfide precipitation resulted in partial cementation of the sediments and was accompanied by $\mathrm{CO}_{2}$ buildup. The loss of permeability coupled with increased $p \mathrm{CO}_{2}$ generated overpressurized pore fluids and eventually resulted in upward migration of metal-laden porewaters. If methanogenesis was active, then this process may also have enhanced the overpressurization of the pore fluids (Kelley et al. 2004). These features are preserved in the HPD as discordant sphalerite- and galena-rich stringers that crosscut laminated sediments during diagenesis (Fig. 8b) (i.e., the "dewatering pipes" of Jonasson and Goodfellow 1986).

\section{Conclusions}

The SIMS in situ sulfur isotope compositions of pyrite from each of the largest deposits within the HPD (i.e., XY, Don, and Anniv) help identify the sources of sulfur and the processes responsible for the formation of the $\mathrm{Zn}-\mathrm{Pb}$ deposits. These processes resulted from combinations of BSR and TSR that took place in the ambient water column (i.e., brine pool near the sediment-water interface), but predominantly occurred within the shallow seafloor subsurface.

SIMS analyses reproduce the secular variability of bulk pyrite $\delta^{34}$ S documented by Goodfellow and Jonasson (1984) for pyrites of the Duo Lake Formation (i.e., CCMS, ACTM, USMS). Our SIMS data show marked differences in the $\delta^{34} S$ values of early framboidal pyrite and later diagenetic pyrite, and they differ from earlier studies because the bulk samples consist mostly of diagenetic pyrite that formed subsequent to framboidal pyrite. The upwardly decreasing sulfur isotope compositions of both sphalerite and galena do not support a model in which the sulfur in these minerals was sourced from ambient biogenic sulfur in a closed basin setting. Conversely, the sulfur isotope compositions of framboidal pyrite indicate that sulfur was sourced by BSR of marine sulfate and we interpret these values to closely reflect the compositions of the ambient sulfidic porewaters prior to the introduction of metalliferous brines. Prior to our work, anoxic and/or euxinic conditions were considered by many workers to be the defining features of the ambient marine paleoenvironment in the HPD. However, the intragranular sulfur isotope variability suggests a dynamic bottom-water environment with respect to redox conditions.

The Selwyn Basin pyrite trend of Goodfellow and Jonasson (1984) incompletely constrains the sulfur isotope evolution of pyrite from one of its type localities. Consequently, it is unlikely that the secular pyrite trend accurately evinces the sulfur isotope composition of the ambient water column. This is due to the fine-grain, multigenerational nature of pyrite from the HPD, where each pyrite textural type records the conditions under which it formed. As such, we emphasize the importance of applying in situ high-spatial resolution analyses in order to extract meaningful genetic and paleoenvironmental information when working with finegrained media.

Acknowledgments This research was jointly funded by NSERC-DG 387591-09, CAMIRO Project 08E04 "Geochemistry of Shales as Vectors to Ore Deposits," and the Targeted Geoscience Initiative 4 Program of the Geological Survey of Canada. We thank Selwyn Chihong Mining Ltd. for providing access to drill core samples and technical information, without which this work could not have been done. We also thank Graham Layne and Glenn Piercey of Memorial University Newfoundland for assistance with SIMS sample preparation and SIMS analyses. We sincerely thank the Society of Economic Geologists Canada Foundation for financial support. Reviews by Karen Kelley, Harald Strauss, Bruce Taylor, and Dave Huston greatly improved this manuscript. This is Geological Survey of Canada contribution 20150476.

Open Access This article is distributed under the terms of the Creative Commons Attribution 4.0 International License (http:// creativecommons.org/licenses/by/4.0/), which permits unrestricted use, distribution, and reproduction in any medium, provided you give appropriate credit to the original author(s) and the source, provide a link to the Creative Commons license, and indicate if changes were made.

\section{References}

Abbott JG, Gordey SP, Tempelman-Kluit DJ (1986) Setting of stratiform, sediment-hosted lead-zinc deposits in Yukon and northeastern British Columbia. In: Morin JA (ed) Mineral deposits of Northern Cordillera: Canadian Institute of Mining and Metallurgy: Special Volume 37:1-18 
Berner RA (1989) Biogeochemical cycles of carbon and sulfur and their effect on atmospheric oxygen over Phanerozoic time. Palaeogeogr Palaeoclimatol Palaeoecol 75:97-122

Berner RA, Raiswell R (1983) Burial of organic carbon and pyrite sulfur in sediments over Phanerozoic time: a new theory. Geochim Cosmochim Acta 47:855-862

Borowski WS, Rodriguez NM, Paull CK, Ussler W III (2013) Are 34Senriched authigenic sulfide minerals a proxy for elevated methane flux and gas hydrates in the geologic record? Mar Pet Geol 43:381395

Brueckner S, Piercey S, Layne G, Piercey G, Sylvester PJ (2015) Variations of sulphur isotope signatures in sulphides from the metamorphosed Ming $\mathrm{Cu}(-\mathrm{Au})$ volcanogenic massive sulphide deposit, Newfoundland Appalachians, Canada. Miner Deposita 50:619-640

Claypool GE, Holser WT, Kaplan IR, Sakai H, Zak I (1980) The age curves of sulfur and oxygen isotopes in marine sulfate and their mutual interpretation. Chem Geol 28:199-260

Coleman ML, Raiswell R (1981) Carbon, oxygen and sulfur isotope variations in concretions from the Upper Lias of N.E. England. Geochim Cosmochim Acta 45:329-340

Cooke DR, Bull SW, Large RR, McGoldrick PJ (2000) The importance of oxidized brines for the formation of Australian Proterozoic stratiform sediment-hosted Pb-Zn (Sedex) deposits. Econ Geol 95:1-18

Crowe DE (1994) Preservation of original hydrothermal $\delta^{34} S$ values in greenschist to upper amphibolite volcanogenic massive sulfide deposits. Geology 22:873

Einsele G (2000) Sedimentary basins: evolution, facies, and sediment budget, 2nd edn. Springer, Berlin, p 792

Eldridge CS, Compston W, Williams IS, Both RA, Walshe JL, Ohmoto H (1988) Sulfur isotope variability in sediment-hosted massive sulfide deposits as determined using the ion microprobe SHRIMP: I, an example from the Rammelsberg orebody. Econ Geol 83:443-449

Eldridge CS, Walshe JL, Compston W, Williams IS, Both RA, Ohmoto H (1989) Sulfur isotope variability in sediment-hosted massive sulfide deposits as determined using the ion microprobe SHRIMP; I, an example from the Rammelsberg orebody; reply. Econ Geol 84:453-457

Eldridge CS, Williams N, Walshe JL (1993) Sulfur isotope variability in sediment-hosted massive sulfide deposits as determined using the ion microprobe SHRIMP: II, a study of the H.Y.C. deposit at McArthur River, Northern Territory, Australia. Econ Geol 88:1-26

Fallick AE, Ashton JH, Boyce AJ, Ellam RM, Russell MJ (2001) Bacteria were responsible for the magnitude of the world-class hydrothermal base metal sulfide orebody at Navan, Ireland. Econ Geol 96:885-890

Froelich PN, Klinkhammer GP, Bender ML, Luedtke NA, Heath GR, Cullen D, Dauphin P, Hammond D, Hartman B, Maynard V (1979) Early oxidation of organic matter in pelagic sediments of the eastern equatorial Atlantic: suboxic diagenesis. Geochim Cosmochim Acta 43:1075-1090

Gadd MG, Layton-Matthews D, Peter JM, Paradis S (2016) The worldclass Howard's Pass SEDEX Zn-Pb district, Selwyn Basin, Yukon. Part I: trace element compositions of pyrite record input of hydrothermal, diagenetic and metamorphic fluids to mineralization. Miner Deposita 51:319-342

Goldhaber MB, Orr WL (1995) Kinetic controls on thermochemical sulfate reduction as a source of sedimentary $\mathrm{H}_{2} \mathrm{~S}$. In: Vairavamurthy M, Schoonen M (eds) Geochemical transformations of sedimentary sulfur: $412-425$

Goodfellow WD (1987) Anoxic stratified oceans as a source of sulphur in sediment-hosted stratiform $\mathrm{Zn}-\mathrm{Pb}$ deposits (Selwyn Basin, Yukon, Canada). Chem Geol: Isot Geosci Sect 65:359-382

Goodfellow WD (2004) Geology, genesis and exploration of SEDEX deposits, with emphasis on the Selwyn basin, Canada. In: Deb M, Goodfellow W (eds) Sediment-hosted lead-zinc sulphide deposits: attributes and models of some major deposits of India, and Canada. Narosa Publishing House, Delhi, pp 24-99
Goodfellow WD, Jonasson IR (1984) Ocean stagnation and ventilation defined by $\delta^{34} \mathrm{~S}$ secular trends in pyrite and barite, Selwyn Basin, Yukon. Geology 12:583-586

Goodfellow WD, Jonasson I (1986) Environment of formation of the Howards Pass (XY) Zn-Pb deposit, Selwyn Basin, Yukon. In: Morin JA (ed) Mineral deposits of Northern Cordillera: Canadian Institute of Mining and Metallurgy: Special Volume 37:19-50

Goodfellow WD, Peter JM (1996) Sulphur isotope composition of the Brunswick No. 12 massive sulphide deposit, Bathurst Mining Camp, New Brunswick: implications for ambient environment, sulphur source, and ore genesis. Can J Earth Sci 33:231-251

Goodfellow WD, Lydon JW, Turner RJW (1993) Geology and genesis of stratiform sediment-hosted (SEDEX) zinc-lead-silver sulphide deposits. In: Kirkham RV, Sinclair WD, Thorpe RI, Duke JM (eds) Mineral deposit modeling: Geological Association of Canada: Special Paper 40:201-251

Hall GEM, Pelchat J-C, Loop J (1988) Separation and recovery of various sulphur species in sedimentary rocks for stable sulphur isotopic determination. Chem Geol 67:35-45

Hammarlund EU, Dahl TW, Harper DAT, Bond DPG, Nielsen AT, Bjerrum CJ, Schovsbo NH, Schönlaub HP, Zalasiewicz JA, Canfield DE (2012) A sulfidic driver for the end-Ordovician mass extinction. Earth Planet Sci Lett 331-332:128-139

Hodder R, Bain DJ, Martel E (2014) Interpretive structural geology map and cross-sections of the Howard's Pass $\mathrm{Pb}-\mathrm{Zn}$ district, Yukon and Northwest Territories. Northwest Territories Geoscience Office, NWT Open File 2014-02, 1 sheet, 1:50000 scale and digital files

Huston DL, Stevens B, Southgate PN, Muhling P, Wyborn L (2006) Australian $\mathrm{Zn}-\mathrm{Pb}-\mathrm{Ag}$ ore-forming systems: a review and analysis. Econ Geol 101:1117-1157

Ireland T, Large RR, McGoldrick P, Blake M (2004) Spatial distribution patterns of sulfur isotopes, nodular carbonate, and ore textures in the McArthur River (HYC) Zn-Pb-Ag deposit, Northern Territory, Australia. Econ Geol 99:1687-1709

Johnson CA, Kelley KD, Leach DL (2004) Sulfur and oxygen isotopes in barite deposits of the western Brooks Range, Alaska, and implications for the origin of the Red Dog massive sulfide deposits. Econ Geol 99:1435-1448

Jonasson IR, Goodfellow WD (1986) Sedimentary and diagenetic textures, and deformation structures within the sulphide zone of the Howards Pass (XY) Zn-Pb deposit, Yukon and Northwest Territories. In: Morin JA (ed) Mineral deposits of Northern Cordillera: Canadian Institute of Mining and Metallurgy: Special Volume 37:51-70

Jones DS, Fike DA (2013) Dynamic sulfur and carbon cycling through the end-Ordovician extinction revealed by paired sulfate-pyrite 834S. Earth Planet Sci Lett 363:144-155

Jørgensen BB, Böttcher ME, Lüschen H, Neretin LN, Volkov II (2004) Anaerobic methane oxidation and a deep H2S sink generate isotopically heavy sulfides in Black Sea sediments. Geochim Cosmochim Acta 68:2095-2118

Kajiwara Y, Krouse HR (1971) Sulfur isotope partitioning in metallic sulfide systems. Can J Earth Sci 8:1397-1408

Kampschulte A, Strauss H (2004) The sulfur isotopic evolution of Phanerozoic seawater based on the analysis of structurally substituted sulfate in carbonates. Chem Geol 204:255-286

Kelley K, Leach D, Johnson C, Clark J, Fayek M, Slack J, Anderson V, Ayuso R, Ridley W (2004) Textural, compositional, and sulfur isotope variations of sulfide minerals in the Red Dog $\mathrm{Zn}-\mathrm{Pb}-\mathrm{Ag}$ deposits, Brooks Range, Alaska: implications for ore formation. Econ Geol 99:1509-1532

Kirkham G, Dunning J, Schleiss W (2012) Update for Don deposit mineral resource estimate, Howard's Pass property, eastern Yukon, Selwyn Resources Ltd., NI 43-101 Technical Report. pp 145 
Leach D, Sangster D, Kelley K, Large RR, Garven G, Allen C, Gutzmer J, Walters S (2005) Sediment-hosted lead-zinc deposits: a global perspective. Econ Geol 100:561-607

Leach DL, Bradley DC, Huston D, Pisarevsky SA, Taylor RD, Gardoll SJ (2010) Sediment-hosted lead-zinc deposits in Earth history. Econ Geol 105:593-625

Leavitt WD, Halevy I, Bradley AS, Johnston DT (2013) Influence of sulfate reduction rates on the Phanerozoic sulfur isotope record. Proc Natl Acad Sci 110:11244-11249

Lydon JW (1983) Chemical parameters controlling the origin and deposition of sediment-hosted stratiform lead-zinc deposits. Short course in sediment-hosted stratiform lead-zinc deposits, short course handbook: $175-250$

Machel HG (2001) Bacterial and thermochemical sulfate reduction in diagenetic settings - old and new insights. Sediment Geol 140: $143-175$

Machel H, Krouse H, Sassen R (1995) Products and distinguishing criteria of bacterial and thermochemical sulfate reduction. Appl Geochem 10:373-389

Magnall JM, Gleeson SA, Stern RA, Newton RJ, Poulton SW, Paradis S (2016) Open system sulphate reduction in a diagenetic environment - isotopic analysis of barite $(\delta 34 \mathrm{~S}$ and $\delta 18 \mathrm{O})$ and pyrite $(\delta$ $34 \mathrm{~S}$ ) from the Tom and Jason Late Devonian $\mathrm{Zn}-\mathrm{Pb}-\mathrm{Ba}$ deposits, Selwyn Basin, Canada. Geochim Cosmochim Acta 180:146-163

Martel E (2015) The structural model for Howard's Pass Pb-Zn district, Northwest Territories: grounds for re-interpretation. Northwest Territories Geological Survey, Yellowknife, p 54

Martel E, Hodder R, Bain DJ (2014) Howard's Pass Zn-Pb SEDEX model needs revisiting: a new interpretation on deformation history [abs.]. Geol Soc America Abs Pgms 46:794

Morganti JM (1979) The geology and ore deposits of the Howards Pass Area, Yukon and Northwest Territories: the origin of basinal sedimentary stratiform sulphides deposits. Unpublished $\mathrm{PhD}$ thesis, University of British Columbia, pp 351

Norford BS, Orchard MJ (1985) Early Silurian age of rocks hosting leadzinc mineralization at Howards Pass, Yukon Territory and District of Mackenzie. Geol Surv Can Pap 83-18:35

Ohfuji H, Rickard D (2005) Experimental syntheses of framboids-a review. Earth Sci Rev 71:147-170

Ohmoto H, Goldhaber MB (1997) Sulfur and carbon isotopes. In: Barnes HL (ed) Geochemistry of hydrothermal ore deposits, 3rd edn. Wiley, New York, pp 517-611

Ohmoto H, Kaiser CJ, Geer KA (1990) Systematics of sulphur isotopes in recent marine sediments and ancient sediment-hosted base metal deposits. In: Herbert $\mathrm{H}, \mathrm{Ho} \mathrm{S}$ (eds) Stable isotopes and fluid processes in mineralization. The University of Western Australia 23:70-120
Peter JM, Shanks WC III (1992) Sulfur, carbon, and oxygen isotope variations in submarine hydrothermal deposits of Guaymas Basin, Gulf of California, USA. Geochim Cosmochim Acta 56:2025-2040

Sangster D, Hillary E (2000) SEDEX lead-zinc deposits: proposed subtypes and their characteristics. Explor Min Geol 7:341-357

Seal RR (2006) Sulfur isotope geochemistry of sulfide minerals. In: Vaughan DJ (ed) Sulfide mineralogy and geochemistry: reviews in mineralogy and geochemistry 61:633-677

Shanks WC, Seyfried WE (1987) Stable isotope studies of vent fluids and chimney minerals, southern Juan de Fuca Ridge: sodium metasomatism and seawater sulfate reduction. J Geophys Res 92:11387

Shanks WC, Woodruff LG, Jilson GA, Jennings DS, Modene JS, Ryan BD (1987) Sulfur and lead isotope studies of stratiform $\mathrm{Zn}-\mathrm{Pb}-\mathrm{Ag}$ deposits, Anvil Range, Yukon; basinal brine exhalation and anoxic bottom-water mixing. Econ Geol 82:600-634

Shanks WCP, Slack JF, Till AB, Thurston R, Gemery-Hill P (2014) Sulfur and oxygen isotopic study of Paleozoic sediment-hosted $\mathrm{Zn}-\mathrm{Pb}(-\mathrm{Ag}-\mathrm{Au}-\mathrm{Ba}-\mathrm{F})$ deposits and associated hydrothermal alteration zones in the Nome Complex, Seward Peninsula, Alaska. Geol Soc Am Spec Pap 506:235-258

Strauss H (1997) The isotopic composition of sedimentary sulfur through time. Palaeogeogr Palaeoclimatol Palaeoecol 132:97-118

Strauss H (1999) Geological evolution from isotope proxy signals - sulfur. Chem Geol 161:89-101

Sweeney R, Kaplan I (1980) Stable isotope composition of dissolved sulfate and hydrogen sulfide in the Black Sea. Mar Chem 9:145-152

Taylor BE (2004) Biogenic and thermogenic sulfate reduction in the Sullivan $\mathrm{Pb}-\mathrm{Zn}-\mathrm{Ag}$ deposit, British Columbia (Canada): evidence from micro-isotopic analysis of carbonate and sulfide in bedded ores. Chem Geol 204:215-236

Taylor BE, Beaudoin G (2000) Sulphur isotope stratigraphy of the Sullivan Pb-Zn-Ag deposit, B.C.: evidence for Hydrothermal sulphur, and bacterial and thermochemical sulphate reduction. In: Lydon JW, Höy T, Slack JF, Knapp ME (eds) The geological environment of the Sullivan deposit, British Columbia: Geological Association of Canada, Mineral Deposits Division, Special Publication No. 1 696-719

Turner RJ (1992) Formation of Phanerozoic stratiform sediment-hosted zinc-lead deposits: evidence for the critical role of ocean anoxia. Chem Geol 99:165-188

Wilkinson JJ (2014) Sediment-hosted zinc-lead mineralization: processes and perspectives. In: Scott SD (ed) Treatise on geochemistry 2nd ed. Elsevier 13: Geochemistry of Mineral Deposits:219-249

Wilkinson JJ, Eyre SL, Boyce AJ (2005) Ore-forming processes in Irishtype carbonate-hosted $\mathrm{Zn}-\mathrm{Pb}$ deposits: evidence from mineralogy, chemistry, and isotopic composition of sulfides at the Lisheen mine. Econ Geol 100:63-86 